\title{
O "ILUMINISMO CONSTITUCIONAL": A ATUAÇÃO DO SUPREMO TRIBUNAL FEDERAL ENTRE A AUTOCONTENÇÃO E O ATIVISMO JUDICIAL
}

CONSTITUTIONAL ENLIGHTENMENT:

THE BRAZILIAN SUPREME COURT DECISIONS BETWEEN SELF-RESTRAINT AND JUDICIAL ACTIVISM

\section{EL "ILUMINISMO CONSTITUCIONAL":}

LA ACTUACIÓN DEL SUPREMO TRIBUNAL FEDERAL ENTRE LA AUTOCONTENCIÓN Y EL ACTIVISMO JUDICIAL

\section{João Paulo K. Forster ${ }^{1}$}

Licença CC BY:

Artigo distribuído sob os termos Creative Commons, permite uso e distribuição irrestrita em qualquer meio desde que o autor credite a fonte original.

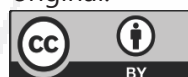

\section{Mártin Haeberlin²}

Resumo: $O$ presente artigo busca compreender a noção de "iluminismo constitucional" partindo da hipótese de que ela não possui caráter iluminista, na medida em que: (i) faz ressurgir a tensão clássica entre o ativismo e a autocontenção judicial; e (ii) retira dos textos o eixo da interpretação. Nessa visada, o artigo é dividido em duas partes, ambas desenvolvidas em pesquisa analítica com metodologia de revisão bibliográfica. Na primeira, analisa os conceitos de autocontenção e ativismo, examinando casos paradigmáticos em sistemas de common law, a fim de evitar sua simples transposição para o Brasil, considerando as diferenças entre os sistemas. Na segunda, estuda o impacto de tais conceitos no Brasil, em particular no Supremo Tribunal Federal, igualmente expondo casos que caracterizam ativismo judicial. Ao final, conclui pela necessidade de distinção entre decisões de vanguarda estabelecidas dentro da multiplicidade de significados extraíveis naturalmente dos textos e das decisões cuja vanguarda advém de uma postura que, mesmo politicamente desejável, é juridicamente inaceitável, em razão de violar uma ética da leitura inerente à autolimitação judicial.

Palavras-chave: lluminismo constitucional. Ativismo judicial. Autocontenção. Supremo Tribunal Federal. Common Law.

1 Doutor em Direito (UFRGS). Mestre em Direito (UFRGS). Coordenador da Pós-Graduação Lato Sensu do Centro Universitário Ritter dos Reis. Professor do Mestrado em Direitos Humanos do Centro Universitário Ritter dos Reis. Advogado. E-mail: joao@forsteradvogados.com.br.

2 Doutor em Direito (PUCRS). Mestre em Direito do Estado (PUCRS). Pós-Doutorado em andamento em Economia (UFRGS), com bolsa da CAPES (Processo n. 23038.004864/2015-63). Pesquisador Visitante do Max-PlanckInstitut für ausländisches öffentliches Recht und Völkerrecht. Professor do Mestrado em Direitos Humanos do Centro Universitário Ritter dos Reis. Advogado. E-mail: mphaeberlin@gmail.com. 
Abstract: This article seeks to understand the notion of "constitutional enlightenment", starting from the hypothesis that it is not enlightening, because: (i) it brings back the classic tension between activism and judicial self-restraint; and (ii) it removes the interpretation from the texts. Considering this intent, the article is divided into two parts. In the first, it analyzes the concepts of self-restraint and activism, examining paradigmatic cases in common law systems, in order to avoid its simple transposition to Brazil, considering the differences between the systems. In the second, it studies the impact of these concepts in Brazil, in particular in the Federal Supreme Court, demonstrating cases that characterize judicial activism. At the end, it concludes that it is necessary to distinguish between avant-garde decisions established within the multiplicity of naturally extractable meanings of texts, and decisions whose avant-garde nature come from a position that, even though politically desirable, is legally unacceptable, as it violates an ethics of reading inherent to judicial restraint.

Key-words: Constitutional Enlightenment. Judicial activism. Self-containment. Federal Court of Justice. Common Law.

Resumen: El presente artículo busca comprender la noción de "iluminismo constitucional" partiendo de la hipótesis de que ella no posee carácter iluminista, en la medida en que: (i) hace resurgir la tensión clásica entre el activismo y la autocontención judicial; y (ii) retira de los textos el eje de la interpretación. En esta visión, el artículo es dividido en dos partes, ambas desarrolladas en investigación analítica con metodología de revisión bibliográfica. En la primera, analiza los conceptos de autocontención y activismo, examinando casos paradigmáticos en sistemas de common law, a fin de evitar su sencilla transposición para Brasil, considerando las diferencias entre los sistemas. En la segunda, estudia el impacto de tales conceptos en Brasil, en particular en el Supremo Tribunal Federal, igualmente exponiendo casos que caracterizan activismo judicial. Al final, concluye con la necesidad de distinción entre decisiones de vanguardia establecidas dentro de la multiplicidad de significados extraíbles naturalmente de los textos y de las decisiones cuya vanguardia advén de una postura que, mismo políticamente deseable, es jurídicamente inaceptable, en razón de violar una ética de la lectura inherente a la autolimitación judicial.

Palabras - clave: Iluminismo constitucional. Activismo judicial. Autocontención. Supremo Tribunal Federal. Common Law.

\section{INTRODUÇÃO}

Quando Immanuel Kant, em 1784, perguntou-se o que era o "iluminismo", ofereceu ele resposta pouco convencional: iluminismo seria a saída do homem de sua menoridade, da qual ele próprio era culpado, por preferir a preguiça de pensar com os outros à coragem de se libertar em pensamento e fazer um uso público e autônomo de sua razão.

Hoje, nossa comunidade jurídica, testemunhando novas interpretações da Constituição lançadas recentemente pelo Supremo Tribunal Federal, tornou

$3 \quad$ KANT, Immanuel. Beantwortung der Frage: Was ist Aufklärung? Berlinische Monatsschrift. Dezember-Heft, 1784, p. 481-494. Disponível em: <http://www.uni-potsdam.de/u/philosophie/texte/kant/aufklaer. htm>. Acesso em: 10 abr. 2018. 
àquela pergunta de Kant, adjetivando-a. Procura-se entender o que é o "iluminismo constitucional", à vista da defesa de um "papel iluminista" do Tribunal por um de seus mais notáveis juízes, o Ministro Luís Roberto Barroso. Em sua dicção, o papel iluminista identifica-se com a função das Cortes Constitucionais de promover avanços civilizatórios na história, a exemplo do que ocorreu com o julgamento do caso Brown v. Board of Education nos Estados Unidos e no reconhecimento das uniões homoafetivas no Brasil. ${ }^{4}$

Interpretar é uma tarefa complexa. Para além de uma multiplicidade de técnicas, aplicáveis a diferentes situações e com diferentes resultados, há uma multiplicidade de olhares, os quais, usando as mesmas técnicas, veem o mundo - e, portanto, os textos - de forma diferente. ${ }^{5}$

No âmbito da interpretação jurídica, a tarefa é edificada. Isso porque, quando se está diante de um intérprete-juiz, o resultado da sua interpretação não é mero "exercício intelectivo", mas comando que vincula pessoas. Isso é: as opções viram autoridade, notadamente nas Cortes Constitucionais, cujas decisões, com efeitos alastrados e em atividade que se confunde com a legislativa, podem alterar profundamente aspectos da vida em sociedade. Para usar alguns exemplos concretos e recentes, diferentes interpretações acerca de regras constitucionais podem: permitir ou proibir a execução provisória de uma sentença penal6; criminalizar ou descriminalizar o aborto

$4 \quad$ A expressão ganhou repercussão por sua recente defesa em texto publicado na Folha de São Paulo (llustríssima. "Operação Abafa" tenta barrar avanços do STF, escreve Barroso. 23.02.2018. Disponível em: <https://www1. folha.uol.com.br/ilustrissima/2018/02/em-artigo-ministro-do-supremo-rebate-criticas-feitas-ao-tribunal.shtml>. Acesso em 24 mar. 2018), na qual respondia às críticas que haviam sido dirigidas ao STF uma semana antes no mesmo jornal, por Conrado Hübner Mendes. Essa não foi a primeira vez, todavia, que o ministro sustentou a necessidade de um "papel iluminista" para as Cortes Constitucionais, incluindo a brasileira. Tal noção já havia sido registrada ao menos em palestra ministrada na Universidade de Harvard em dezembro de 2015 (Fonte: Judicialização não se confunde com ativismo judicial, afirma Barroso. Consultor Jurídico. Disponível em: <https:// www.conjur.com.br/2015-dez-07/judicializacao-nao-confunde-ativismo-judicial-barroso>. Acesso em: 24 mar. 2018). Posteriormente, viu-se mais bem elaborada no texto: BARROSO, Luís Roberto. Posfácio. Contramajoritário, representativo e iluminista: o Supremo, seus papéis e seus críticos. In: VIEIRA, Oscar Vilhena; GLEZER, Rubens. A Razão e o Voto: diálogos constitucionais com Luís Roberto Barroso. Rio de Janeiro: FGV Editora, 2017.

5 "One judge looks at problems from the point of view of history, another from that of social utility, one is a formalist, another a latitudinariam, one is timorous of change, another dissatisfied with the present; out of the attrition of diverse minds there is beaten something which has a constancy and uniformity and average value greater than its component elements. The same thing is true of the work of juries." CARDOZO, Benjamin. The nature of the judicial process. New York: Dover Publications, 2005. p. 173.

6 Essa discussão é travada pelo STF sobre a regra do artigo $5^{\circ}$, LVII, da CF, entendendo o Tribunal, em medida cautelar, pela possibilidade de execução provisória, atribuindo-se interpretação conforme a Constituição ao artigo 283 do Código de Processo Penal. BRASIL. Supremo Tribunal Federal. Ação Declaratória de Constitucionalidade n. 43 e 44. Relator para acórdão Min. Edson Fachin, 2016. 


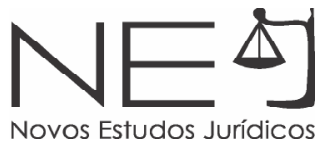

nos primeiros meses de gestação7; reconhecer ou relegar juridicamente a união entre pessoas de mesmo sexo; ${ }^{8}$ atribuir ou negar imunidade tributária ao livro eletrônico ${ }^{9}$. O presente artigo parte da hipótese, contudo, de que a defesa de um "papel iluminista" das Cortes Constitucionais é menos iluminista do que pretende. Isso porque ela (i) não inova, mas apenas faz ressurgir a tensão clássica entre o ativismo e a autocontenção judicial; e, nesse contexto, (ii) acaba por deslocar o eixo da interpretação do lugar onde ela deve estar: o texto. Trata-se, pois, de uma tomada de posição naquela tensão clássica, para a qual se deu nome diverso.

Na visada dessa hipótese, e considerando a importância de entender a opção e suas consequências, o artigo divide-se em duas partes, ambas desenvolvidas em pesquisa analítica com metodologia de revisão bibliográfica. Na primeira, busca-se resgatar os significados do judicial activism e do judicial restraint a partir de decisões paradigmáticas do sistema do common law sobre o tema, para compreender, desde esses conceitos fundamentais, por nós importados, quais as consequências de uma ou de outra vertente. Na segunda parte, elucidar-se-á a influência do ativismo no Brasil e suas consequências, em algumas decisões também paradigmáticas prolatadas na última década.

\section{AUTOCONTENÇÃO JUDICIAL (JUDICIAL SELF RESTRAINT) E ATIVISMO JUDICIAL (JUDICIAL ACTIVISM)}

\subsection{PELA BUSCA DE UM SIGNIFICADO}

A palavra ativismo é polissêmica, encontrando diferentes significados para diferentes ocasiões. $O$ ativismo a ser conceituado não é aquele que diferencia o juiz ativo do juiz passivo, desprovido de poderes para ordenar o impulso do

$7 \quad$ Essa discussão foi travada pela Primeira Turma do STF sobre as regras dos artigos 124 e 126 do Código Penal, entendendo a Turma pela descriminalização do aborto nos três primeiros meses de gestação, com base no princípio da proporcionalidade. BRASIL. Supremo Tribunal Federal. Habeas Corpus n. 124.306. Relator para acórdão Min. Roberto Barroso, 2016.

8 Essa discussão foi travada pelo STF sobre a regra do art. 226, $\S 3^{\circ}$, da CF, entendendo o Tribunal pelo reconhecimento da união homoafetiva, fundamentada no princípio da não discriminação. BRASIL. Supremo Tribunal Federal. Arguição de Descumprimento de Preceito Fundamental n. 132. Relator Min. Ayres Britto, 2011; e BRASIL. Supremo Tribunal Federal. Ação Direta de Inconstitucionalidade n. 4277. Relator Min. Ayres Britto, 2011.

9 Essa discussão foi travada pelo STF sobre a regra do art. 150, VI, "d", da CF, na qual foi fixado o tema 593 de repercussão geral, sob a seguinte Tese: "A imunidade tributária constante do art. 150, VI, d, da CF/88 aplica-se ao livro eletrônico (e-book), inclusive aos suportes exclusivamente utilizados para fixá-lo." BRASIL. Supremo Tribunal Federal. Recurso Extraordinário n. 330.817. Relator Min. Dias Toffoli, 2017. 
feito e desinteressado com a demanda posta a julgamento ${ }^{10}$. Trata-se de outra perspectiva, do grau de liberdade que o julgador, em particular o magistrado das Cortes Superiores, exerce no momento decisório. ${ }^{11}$

O debate acerca do ativismo judicial tem raízes na Common Law, em particular nos Estados Unidos. ${ }^{12}$ No entanto, mesmo naquele país, o debate a respeito do tema encontra diferentes significados, que devem ser associados, tanto a autocontenção quanto o ativismo, à possibilidade do juiz de criar a lei. Se não há esta possibilidade, não se pode falar em ativismo.13

Para Riccardo Guastini, o judicial restraint, aqui traduzido como autocontenção ${ }^{14}$, é inspirado no alto valor que se dá ao legislador democrático, uma vez que os juízes são desprovidos de tal predicado (democrático) e, como pressuposto, "não devem invadir a competência do legislativo." ${ }^{15}$ Esta vertente haveria de privilegiar não só o uso mais comum das palavras como também o original intent, a intenção original dos autores do texto legal ${ }^{16}$. Acrescenta o jurista italiano que o intérprete que pratica a autocontenção também respeita interpretações já consolidadas em decisões anteriores, ou seja, supostamente adota postura de não modificar os precedentes. ${ }^{17}$ Pareceria evidente que, nessa

10 Nesse jaez, bem assinala José Roberto dos Santos Bedaque que não se pode sonegar ao Estado o reconhecimento de sua autoridade, que não se confunde com autoritarismo ou ditadura. BEDAQUE, José Roberto dos Santos. Poderes Instrutórios do Juiz. 4 ed. São Paulo: RT, 2009. p. 76-77

11 Endereça-se aqui à noção de "juiz criador do direito" e suas respectivas críticas. Cf. TERRÉ, François. Un juge créateur de droit? Non merci! La Création du droit par le juge. Archives de philosophie du droit. Tomo 50. Paris: Dalloz, 2007.

12 GUASTINI, Riccardo. Interpretare e Argomentare. Milano: Giuffrè, 2011. p. 445.

13 BARAK, Aharon. The Judge in a Democracy. New Jersey: Princeton University Press, 2006. p. 264.

14 Termo já anteriormente empregado em: DIMOULIS, Dimitri, LUNARDI, Soraya Gasparetto. Ativismo e Autocontenção judicial no controle de constitucionalidade. In: As novas faces do ativismo judicial. Salvador: Juspodium, 2011. p. 459 e seguintes.

15 GUASTINI, Riccardo. Interpretare e Argomentare. p. 445.

16 Essa questão descortina outro tema relevante, porém tangente à proposta do presente texto, qual seja, o debate entre os autores chamados "interpretativistas" sobre a dificuldade de resgatar a intenção dos founding fathers. No caso particular dos Estados Unidos, é curioso que um dos próprios fathers of the Constitution, James Madison, tenha rejeitado a possibilidade de "intenção original", registrando que os "debates e decisões incidentais da Convenção não podem ter qualquer caráter de autoridade." Destaca-se, ainda, que a Convenção para elaboração do texto adotou uma regra de sigilo, de que nada discutido nesses encontros fosse impresso ou publicado sem prévia autorização. Cf. LEVY, Leonard W. Original Intent and the Framer's Constitution. New York: Macmillan Publishing Co., 1988. p. 1-3. Interpretar a intenção original talvez fosse um perigo para os Founding Fathers, que pareciam desejar uma análise mais literal do texto do que outra que concedesse maior liberdade ao Judiciário. Cf. CARTER, John Denton. The Warren Court and the Constitution. Lousiana: Pelican Publishing Company, 1973. p. 155.

17 GUASTINI, Riccardo. Interpretare e Argomentare. p. 445-446. Tanto o literalismo quanto o originalismo (em sua perspectiva subjetiva ou objetiva) possuem uma série de críticas que não serão abordadas aqui. 
cruzada pelo respeito à separação de poderes e à democracia, as matérias não tratadas de modo algum pela Constituição outorgam plena liberdade ao legislador para regrar qualquer conduta da maneira que melhor entenda. ${ }^{18}$ De outro lado, o ativismo inspira-se no valor da congruência do Direito com a consciência social, imbuindo o julgador das vestes de protetor das minorias contra as maiorias políticas, em uma leitura "livre" da Constituição para adaptá-la às necessidades da vida real, "que os juízes só podem identificar mediante seus sentimentos de justiça" ${ }^{19}$

É um erro afirmar que a autocontenção judicial é adotada por juízes conservadores e o ativismo por juízes liberais. Tais termos, conservadorismo e liberalismo, demonstram bem o resultado da atividade judicial, mas não o modo pelo qual ela se desenvolve. ${ }^{20}$ Nesse sentido, a Suprema Corte norte-americana era, na década de 30, ativista e conservadora, invalidando um grande número de leis que reconheciam direitos individuais. A chamada "Warren Court" da década de 70 era liberal e ativista. ${ }^{21} \mathrm{~A}$ atual composição da Corte é vista como realizadora de um ativismo judicial de viés conservador. ${ }^{22}$ Veja-se, pois, que a análise da história da Supreme Court rende diferentes conclusões, a partir do conceito que se tem de ativismo e autocontenção, a ponto de se afirmar que o ativismo sempre caracterizou sua atividade. ${ }^{23}$ A fim de clarear os conceitos, até para não incorrer nessas imprecisões, pode-se concluir que ativismo e autocontenção são importantes quanto ao modo de julgar, e não propriamente indicativos do resultado esperado. $\mathrm{O}$ que se deve sublinhar inicialmente, em se

18 GUASTINI, Riccardo. Teoria e Ideologia da Interpretação Constitucional. Interesse Público, Sapucaia do Sul, v. 8, n. 40, p. 217-256, nov. 2006, p. 237.

19 GUASTINI, Riccardo. Interpretare e Argomentare. p. 446.

20 BARAK, Aharon. The Judge in a Democracy. New Jersey: Princeton University Press, 2006. p. 267.

21 À época do juramento de Earl Warren como Chief Justice da Supreme Court, em mandato que duraria 16 anos, não havia motivos para crer que seu mandato seria um dos mais controversos períodos na história daquela Corte. Desde o Justice John Marshall e talvez do precedente Dred Scott v. Sandford, nunca a Corte havia sido alvo de tanta atenção. CARTER, John Denton. The Warren Court and the Constitution. p. 3.

22 CHEMERINSKY, Erwin. Conservative Judicial Activism. Loyola of Los Angeles Law Review, v. 44, 2010-2011, p. 863. Élisabeth Zoller entende que a Suprema Corte simplesmente não tem mais o poder que possuía outrora, sendo irônico que, apesar do triunfo do realismo histórico, a Corte perdeu os meios "políticos de colocar em obra os imensos poderes que a teoria lhe outorgava", suscitando, hoje, tanto esperança quando desilusões aos jurisdicionados. ZOLLER, Élisabeth. La Cour suprême des États-Units entre création et destruction du droit. La Création du droit par le juge, Archives de philosophie du droit, T. 50. Paris: Dalloz, 2007, p. 287.

23 LEVY, Leonard W. Original Intent and the Framer's Constitution. New York: Macmillan Publishing Co., 1988. p. 56. 
tratando de ativismo, é que ele nunca serviu de justificativa para decisão contrária à lei. Em verdade, nenhuma das duas correntes autoriza decisões contra legem, mas sim dentro da zona de razoabilidade judicial. ${ }^{24}$ Tampouco um juiz que joga uma moeda para decidir um caso age em qualquer das duas vertentes, mas, simplesmente, de modo ilegítimo ${ }^{25}$, como se poderia dizer de membro do Poder Executivo em sua sujeição às leis e aos comandos do Poder Judiciário. ${ }^{26}$

A lei, em Estado Democrático de Direito, é elaborada por legisladores eleitos. Vem do sufrágio a legitimidade das leis. O ponto de partida do juiz deve ser a lei positivada e, se contrária à Constituição, aí sim se fará necessário o trabalho de sua adequação ao ordenamento. Nas palavras de Alexander Hamilton, no artigo LXXVIII de O Federalista:

Não é admissível supor que a Constituição tenha tido a intenção de facultar os representantes do povo para substituir a sua vontade à de seus eleitores. É muito mais racional entender que os tribunais foram concebidos como um corpo intermediário entre povo e a legislatura, com a finalidade, entre várias outras, de manter esta última dentro dos limites atribuídos à sua autoridade. A interpretação das leis é própria e peculiarmente da incumbência dos tribunais. [...] Esta conclusão não supõe de nenhum modo a superioridade do poder judicial sobre o legislativo. Somente significa como o poder do povo é superior a ambos e que onde a vontade da legislatura, declarada em suas leis, se acha em oposição com a do povo, declarada na Constituição, os juízes deverão ser governados pela última de preferência às primeiras. Deverão regular suas decisões pelas normas fundamentais e não pelas que não o são. ${ }^{27}$

24 BARAK, Aharon. The Judge in a Democracy. p. 270-271.

25 BARAK, Aharon. The Judge in a Democracy. p. 264.

26 Exemplo interessante, nesse sentido, ocorreu a partir do caso Dred Scott v. Sandford, que decidiu uma questão envolvendo a escravatura de maneira pró-restrição da liberdade. Na ocasião, Lincoln afirmou que discordava da decisão, oferecendo resistência ao julgado na esperança de que fosse modificado, mas jamais defendeu a desobediência a ordens judiciais. Cf. BICKEL, Alexander M. The Least Dangerous Branch. 2 ed. New Haven: Yale University Press, 1986. p. 259-260.

27 HAMILTON, Alexander; JAY, John; MADISON, James. O Federalista. Rio de Janeiro: Editora Nacional de Direito, 1959. p. 314. Esse pensamento foi também consolidado no julgamento Marbury v. Madison (1 Cranch - 5 U.S. - 137; 2 L. Ed. 60 - 1803), nas razões do Chief Justice Marshall, que afirmou ser a Constituição "a Lei Suprema de uma nação". Cf. MENEZ, Joseph F.; VILE, John R. Summaries of leading cases on the constitution: 50th anniversary edition. Lanham: Rowman \& Littlefield Publishers, 2004, p. 123-125. Disponível em: <http://caselaw. Ip.findlaw.com/scripts/getcase.pl?court=us\&vol=5\&invol=137>. Acesso em: 18 abr. 2018. 
Não havendo correlação entre liberalismo ou conservadorismo e ativismo ou autocontenção, faz-se necessário distinguir o modus de cada uma dessas tendências. Tendências, pois nenhum juiz pode ser rotulado como integralmente ativista ou autocontido, já que, no enorme escopo de atuação do juiz, ele poderá modificar a forma como decide, contanto que siga atendendo os deveres que se lhe impõe, como o da motivação das decisões judiciais, a qual assume ainda maior relevância em um cenário de ativismo. ${ }^{28}$

O ativismo configura-se a partir de uma postura que tende a buscar equilíbrio entre valores sociais conflitantes (como entre direitos individuais e da coletividade), por meio da mudança de leis existentes ou da criação de novas leis $^{29}$ na lacuna do Poder Legislativo, sem hesitar em alterar os entendimentos antes fixados pelos precedentes ou por políticas fixadas em outros ramos do Estado (no Poder Executivo ou Legislativo, portanto). ${ }^{30}$ A postura ativista também valoriza mais os obiter dicta encontrados em um julgado, tanto ou mais que a própria ratio decidendi do mesmo. ${ }^{31} \mathrm{O}$ ativismo não se confunde, portanto, com o exercício arbitrário das próprias razões privadas do juiz ou com a noção de criação judicial de políticas públicas. Trata-se da perspectiva de uma atuação judicial "legisladora", ainda que subsidiária e ocasionalmente. ${ }^{32}$ Significados outros corromperiam o termo, ao menos em sua origem. ${ }^{33}$

28 A tarefa é tornar o ato de julgar o mais racional, consciente e expresso possível, ainda que uma dose de subjetividade das decisões seja irremovível. Tão mais confiável é um argumento quanto mais possa ser ele articulado além de nossas emoções, sendo tal articulação um "ingrediente fundamental de um ato de confiança responsável.” ORIGGI, Gloria. Qu'est-ce que la confiance? Paris: Librairie Philosophique J. Vrin, 2008. p. 32.

29 O que alguns autores simplesmente entendem como sendo impróprio à função judicial. Por todos, POPOVIC, Dragoljub. Prevailing of judicial activism over self-restraint in the jurisprudence of the european court of human rights. Creighton Law Review, vol. 42, 2008-2009, p. 364.

30 BARAK, Aharon. The Judge in a Democracy. p. 271.

31 Geralmente, os obiter dicta são definidos como tudo que "no contexto da motivação, não fazem parte de uma argumentação justificativa específica ou não constituem um elemento dotado de função justificativa autônoma". TARUFFO, Michele. La motivazione della sentenza civile. Padova: CEDAM, 1975. p. 312. Rupert Cross reconhece, no sistema anglo-saxão, a distinção entre os obiter dicta e a ratio decidendi. No entanto, aponta que é de extrema dificuldade a separação precisa de ambos." CROSS, Rupert, HARRIS, J. W. Precedent in English Law. Oxford: Clarendon Press, 2004. p. 41. Na verdade, o direito continental também reconhece sua existência, valorizando seu papel, como no caso do precedente Fraisse, de 2 de junho de 2000, da Cour de Cassation francesa. CANIVET, Guy. Activisme judiciaire et prudence interpretative. La Création du droit par le juge, Archives de philosophie du droit, T. 50. Paris: Dalloz, 2007. p. 31.

32 POSNER, Richard. How Judges Think. Cambridge: Harvard University Press, 2008. p. 81 e seguintes.

33 O termo, que visava apenas descrever decisões politicamente progressistas que podiam representar uma ameaça à democracia, foi empregado pela primeira vez em 1947 por Arthur Schlesinger Jr., comentando a atuação da Supreme Court na época do New Deal. Cf. DIMOULIS, Dimitri, LUNARDI, Soraya Gasparetto. Ativismo e Autocontenção judicial no controle de constitucionalidade. 
Nesse contexto, cabe ponderar que a posição de Riccardo Guastini, de que o juiz autocontido é aquele que respeita precedentes, não se mostra adequada. A autocontenção judicial estaria fadada à extinção caso não pudesse alterar precedentes de juízes ativistas. Da mesma forma, juízes ativistas não agem de maneira completamente imprevisível, alterando todo e qualquer julgado. A autocontenção aproxima-se muito mais de uma tendência do julgador a decidir conflitos preservando a lei existente em vez de criar uma nova lei, o que acaba o tornando relutante a invalidar leis proclamadas. O ativista, ao contrário, não hesita em declarar a inconstitucionalidade de alguma lei ou em se desvincular de precedentes ou atos normativos; nem hesita em criar novas normas a partir do texto existente. ${ }^{34}$

Por essas razões que os conceitos de ativismo e autocontenção precisam ser encarados como tendências dos julgadores (não como modelos estanques). Nenhuma delas advoga atividade arbitrária e descomprometida do Estado com a lei, o que significaria endossar o arbítrio da atividade estatal com o cidadão na realização de seus direitos fundamentais. Aos julgadores garantese independência para a imparcialidade, não para a arbitrariedade. ${ }^{35}$ A própria ideia de democracia só sobrevive se compatível com os direitos individuais dos cidadãos, o que implica o respeito do magistrado por sua devida função no Estado Democrático de Direito. ${ }^{36}$

\subsection{DIFERENTES PERSPECTIVAS MUNDIAIS}

Estabelecidas as bases conceituais de ambas as vertentes, foram selecionados cinco casos de países de Common Law a fim de fixar e esclarecer as conclusões até então apresentadas. São eles: a) Mabo v. Queensland (Austrália); b) Richards v. Secretary of State for Work \& Pensions (Tribunal de Justiça da União Europeia); c)

34 BARAK, Aharon. The Judge in a Democracy. p. 271-272.

35 Não há dúvida de que o Poder Judiciário deve ser independente em relação aos demais poderes, e que também deva ser fortalecido o suficiente para que demais entidades ou grupos não estatais o pressionem. A independência não pode ser entendida, porém, fora de separação absoluta da realidade, o que terminaria por criar verdadeira aberração jurídica. ZAFFARONI, Eugenio Raúl. Poder Judiciário: crise, acertos e desacertos. Tradução de Juarez Tavares. São Paulo: RT, 1995. p. 90. Nesse sentido, Aharon Barak lembra um ditado talmúdico a respeito dos juízes: "Você acha que estou lhe dando poder? É escravidão que estou impondo a você." BARAK, Aharon. The Role of a Supreme Court in a Democracy. Hastings Law Journal, v. 53, 2001-2002, p. 1216.

WALDRON, Jeremy. Law and Disagreement. Oxford: Oxford University Press. p. 282. 


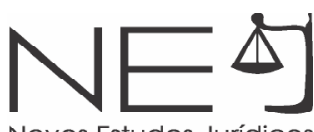

State v. Makwanyane (África do Sul); d) President of the Republic of South Africa $v$ Hugo (África do Sul) ${ }_{i}^{37}$ e) Berghuis v. Thompkins (Estados Unidos da América).

No primeiro desses casos, Mabo v. Queensland (No 2) ${ }^{38}$, de 1992, encontra-se decisão da Alta Corte da Austrália reconhecendo o direito dos aborígenes à parte do território australiano, revendo decisão anterior, que havia adotado a doutrina da terra nullius, afirmando que, como não se tratava de estado soberano, a simples ocupação dos terrenos pelos colonizadores havia lhes garantido justo título, nada podendo reclamar os habitantes originais. $O$ caso é peculiar, pois envolve não só uma questão étnica e ainda bastante atual, mas também surpreende, pois se trata de uma mudança do entendimento antes consolidado nos precedentes, e de uma decisão que se deu por conta de lacuna legislativa.

Eddie Mabo, um dos autores da demanda, ingressou em juízo representando os nativos Meriam das Ilhas Murray. Eles deduziram seus direitos em juízo pedindo o reconhecimento de seu direito de propriedade sobre esse território, afirmando que desde a promessa, em 1967, da realização de um referendo, nada havia sido feito a fim de lhes garantir tal direito. No seu voto, o Justice Brennan assim se pronunciou:

O common law não necessariamente se conforma com o direito internacional, mas o direito internacional é uma influência legítima e importante no desenvolvimento do common law, especialmente quando o direito internacional declara a existência universal dos direitos humanos. Uma doutrina de common law fundada em discriminação injusta no gozo dos direitos civis e políticos exige reconsideração. É contrário tanto aos standards de direito internacional com os valores fundamentais de nosso common law introduzir uma regra discriminatória que, por causa da suposta posição na escala da organização social dos habitantes originais de uma colônia, nega a eles o direito a ocuparem suas terras nativas. ${ }^{39}$

A decisão pode ser facilmente enquadrada como ativista e liberal, na medida em que os juízes exerceram função criadora do direito, preenchendo a

$37 \quad$ A África do Sul é um país que oferece rico material de análise no tema em questão, diante de sua problemática experiência com o Apartheid, e de como sua Corte Superior vem enfrentando julgamentos extremamente delicados numa história muito recente de conflito racial extremado. Para maior detalhe, vide: CORDER, Hugo. Judicial Activism of a Special Type: South Africa's Top Courts since 1994. In: DICKSON, Brice (org.). Judicial Activism in Common Law Supreme Courts. Oxford: Oxford University Press, 2007. p. 323-362.

38 WHEELER, Fiona, WILLIAMS, John. 'Restrained Activism' in the High Court of Australia. In: DICKSON, Brice (org.). Judicial Activism in Common Law Supreme Courts. Oxford: Oxford University Press, 2007. p. 32-34.

39 WHEELER, Fiona, WILLIAMS, John. 'Restrained Activism' in the High Court of Australia. p. 36. 
lacuna legal acerca da matéria, reformando entendimento previamente fixado no julgamento do caso Milirrpum v Nabalco Pty Ltd (1971). ${ }^{40}$ Já no segundo caso, Richards v. Secretary of State for Work \& Pensions ${ }^{41}$, foi tomada decisão envolvendo direitos LGBT no Tribunal de Justiça da União Europeia. O caso se originou na Inglaterra, por conta de um homem que realizou cirurgia de alteração de sexo para se tornar mulher, e requereu o benefício de aposentadoria aos 60 anos, conforme permitido para o sexo feminino. No entanto, como, na Inglaterra, não se alterava, à época, o gênero do registro civil mesmo após a cirurgia de mudança de sexo, o entendimento das autoridades locais foi de que não se concederia a aposentadoria a não ser quando ele completasse 65 anos de idade.

O argumento do governo inglês foi o de que não havia qualquer relevância na discriminação dos transexuais a questão da concessão de aposentadorias. De seu lado, o Tribunal de Justiça da União Europeia entendeu que se tratava de violação ao tratamento igualitário e, assim, caracterizava como discriminação ilegal. Muito embora o caso tenha origem na Inglaterra, onde a discussão do ativismo voltada à revisão judicial teria importância relativizada ${ }^{42}$, a decisão desta Corte acabou ressoando por todos os países integrantes da União Europeia, independentemente da dicção constitucional a esse respeito. ${ }^{43} \mathrm{~A}$ decisão revelouse ativista e liberal, alterando a política até então estabelecida no âmbito do Executivo inglês, e criando uma diretiva que, posteriormente, acabou inspirando a legislação em vários países da União Europeia, inclusive na própria Inglaterra.

O caso State v. Makwanyane ${ }^{44}$, por seu turno, apresenta uma decisão de cunho ativista e liberal na África do Sul. A Constituição sul-africana de 1996 não aboliu a pena de morte, vigente no país à época deste julgamento, e de ampla utilização para apenados pobres e negros. A Constituição, no entanto, assegurou o direito à vida, silenciando quanto à pena de morte. Nesse âmbito, a decisão foi considerada ativista, declarando inconstitucional tal pena, com fundamento na

$40 \quad$ Milirrpum v Nabalco Pty Ltd, (1971) 17 FLR 14.

41 O julgamento ocorreu em 2006. Decisão disponível em: <http://curia.europa.eu/juris/liste.jsf? language $=$ en\&num $=C-423 / 04 .>$ Acesso em 10.04.2018.

42 BARAK, Aharon. The Judge in a Democracy. p. 266.

43 WAELE, Henri de, VLEUTEN, Ana van der. Judicial activism in the european court of justice - the case of LGBT rights. Michigan State University Journal of International Law, vol. 19, p. 2010-2011, p. 656-657.

44 Disponível em: <http://www.saflii.org/za/cases/ZACC/1995/3.html>. Acesso em 05.04.2018. 
vedação de penas cruéis, desumanas ou degradantes, sendo contrária ao sistema de uma África do Sul democrática. ${ }^{45}$ Ainda na África do Sul, em outro caso, o Presidente Mandela havia assinado um decreto determinando o perdão da pena de prisão para mulheres condenadas por crimes não violentos, por período não superior a determinado tempo, cujos filhos tivessem menos de 12 anos de idade. O caso President of the Republic of South Africa $v$ Hugo discutia a igualdade entre homens e mulheres, apontando que a decisão presidencial era discriminatória ao presumir que só a mãe poderia ser cuidadora de seus filhos, e que os pais não tinham importância no desenvolvimento de uma criança. A decisão foi de, por maioria, reconhecer a constitucionalidade do decreto, num julgamento que causou grande desconforto à Corte por manter a constitucionalidade de um decreto que era, em maior ou menor medida, discriminatório. ${ }^{46}$ Não resta dúvida de que tal decisão foi, ao mesmo tempo, autocontida e liberal, reconhecendo direitos a uma minoria, mas sem a modificação da lei editada.

Finalmente, nos Estados Unidos, o caso Berghuis v. Thompkins ${ }^{47}$ modificou o clássico entendimento cristalizado no julgamento Miranda v. Arizona ${ }^{48}$, de que, para o cidadão sob custódia do Estado renunciar à garantia prevista na Quinta Emenda, que afasta a possibilidade de autoincriminação, deveria haver renúncia clara e expressa, declarando o acusado ter compreendido os direitos constantes da Miranda clause. No novo julgamento, a Supreme Court modificou este entendimento, por maioria, a fim de que a renúncia ao direito ao silêncio não precisa ser expressa, podendo ser implícita. ${ }^{49}$ Tratou-se de uma revisão do entendimento estabelecido previamente (ativista), mas de viés conservador.

Verifica-se, a partir desses exemplos, que diferentes contextos culturais e diferentes momentos históricos propiciam diferentes oportunidades para ativismo

45 CORDER, Hugo. Judicial Activism of a Special Type: South Africa's Top Courts since 1994. p. 332.

46 CORDER, Hugo. Judicial Activism of a Special Type: South Africa's Top Courts since 1994.

47 Berghuis v. Thompkins (No. 08-1470), 547 F. 3d 572. Disponível em: <http://www.law.cornell.edu/supct/html/081470.ZS.html >. Acesso em 09.04.2018.

48 Miranda v. Arizona (No. 759), 98 Ariz. 18, 401 P.2d 721.

49 CHEMERINSKY, Erwin. Conservative Judicial Activism. Loyola of Los Angeles Law Review, v. 44, $2010-2011$. p. 879-880. O acusado foi preso e interrogado durante mais de duas horas e meia, ficando em silêncio a maior parte do tempo. Ultrapassado esse período, os policiais perguntaram a Thompkins, que estava sob custódia, se ele acreditava em Deus, ao que respondeu "sim", oferecendo resposta afirmativa quando perguntado se rezava a Deus. Instado se ele rezava a Deus para que o perdoasse por ter atirado naquele menino, ele também respondeu que sim. Essa evidência foi seriamente considerada em seu julgamento, pesando em seu desfavor e acarretando o veredito de culpado. 
e autocontenção, liberalismo e conservadorismo, não sendo as rotulações realizadas indenes à crítica. Importante registrar que tais casos não podem ser simplesmente transpostos e aplicados no Brasil, pela total diferença constitucional e histórica com esses países. Deve-se, a partir dos conceitos antes desenvolvidos, analisar-se os precedentes propriamente brasileiros, a fim de que possa melhor se compreender a extensão do self-restraint e do activism neste país específico.

\section{EFEITOS DO ATIVISMO NO BRASIL}

\subsection{ATIVISMO NO BRASIL}

Tem-se testemunhado, no Brasil, um progressivo protagonismo do Judiciário, nítido na atenção dada à mais alta corte do país. Esse movimento não é autóctone. Ao contrário, se o vivencia ao redor do mundo, pelos mais diversos motivos. Um deles seria a expansão do mercado em relação à qual os tribunais seriam um meio mais dinâmico e isento para garantir "a segurança jurídica, estabilidade e previsibilidade do que legisladores democráticos"50. Já em outra perspectiva, essa expansão seria decorrente da

[...] retração do sistema representativo e de sua incapacidade de cumprir as promessas de justiça e igualdade, inerentes ao ideal democrático e incorporadas nas constituições contemporâneas. Neste momento, recorre-se ao judiciário como guardião último dos ideais democráticos. O que gera, evidentemente, uma situação paradoxal, pois, ao buscar suprir as lacunas deixadas pelo sistema representativo, o judiciário apenas contribui para a ampliação da própria crise de autoridade da democracia. ${ }^{51}$

Em particular no caso brasileiro, a Constituição de 1988 é extremamente abrangente, diferentemente do que se verifica na Constituição dos Estados Unidos da América, por exemplo. Isso se deve à desconfiança do constituinte no legislador infraconstitucional ${ }^{52}$, sob a ilusão da possibilidade de elaboração de uma Carta Constitucional "completa", incorporando diversos temas que eram exclusivos de legislação ordinária, como no caso da Lei de Introdução às Normas do Direito Brasileiro (LINDB) no tocante, por exemplo, ao direito adquirido, à coisa julgada e ao ato jurídico perfeito.

50 VIEIRA, Oscar Vilhena. Supremocracia. Revista Direito GV, São Paulo: RT, v. 8, jul./dez.2008. p. 442.

51 VIEIRA, Oscar Vilhena. Supremocracia. p. 443.

52 VIEIRA, Oscar Vilhena. Supremocracia. p. 443. 
Assim, o Supremo Tribunal Federal, que já acumulava, desde 1988, todas as funções típicas de um Tribunal Constitucional, sendo um órgão de cúpula do Poder Judiciário e também um foro especializado, a partir das Emendas Constitucionais 3/93 e 45/04, tornou-se "uma instituição singular em termos comparativos." ${ }^{53}$ Portanto, não bastasse a existência de uma Constituição abrangente, outros fatores acabaram contribuindo para o recente protagonismo do Supremo Tribunal Federal. Soma-se a isso, ainda, a inércia do Legislativo em questões polêmicas, o que levou a Corte a se debruçar a respeito de temas originalmente estranhos à sua competência. A partir dos conceitos anteriormente estabelecidos, cabe considerar que não é possível um simples transporte do tema do ativismo para o direito brasileiro.

Utilizando-se os Estados Unidos como paradigma em matéria de ativismo judicial, encontram-se entre esses países várias diferenças. Com efeito, se a cisão common law / civil law já não é mais tão relevante - frente à colocação, em nosso ordenamento, da súmula vinculante ${ }^{54}$, e da crescente importância da legislação para o common law estadunidense -, ainda desempenha papel considerável. As decisões da Suprema Corte norte-americana não só definem a controvérsia para as partes envolvidas, mas também possuem força de precedente, conforme a doutrina do stare decisis. Há de se afirmar que, a partir da criação da Súmula Vinculante, é que o Supremo Tribunal Federal, criado em 1891, realmente passou a exercer a autoridade que the cabe a fim de governar jurisdicionalmente o Poder Judiciário no Brasili5, sendo que a repercussão geral e o julgamento de demandas repetitivas também acabam por aumentar esse poder.

53 VIEIRA, Oscar Vilhena. Supremocracia. p. 444.

54 E da própria doutrina, crescente, que desenvolve o tema dos precedentes no âmbito do ordenamento pátrio: "A força obrigatória dos precedentes constitucionais obviamente não deriva de as decisões proferidas em ação direta produzirem coisa julgada erga omnes e eficácia vinculante. Os precedentes constitucionais sempre devem ter eficácia obrigatória, não importando se há controle concentrado. (...) Basta pensar na ideia de se atribuir eficácia vinculante aos motivos determinantes das decisões proferidas em ação direta. Como é óbvio, esta ideia não proveio da natureza do controle objetivo, mas da mera necessidade de se dar força aos fundamentos das decisões proferidas pelo Supremo Tribunal Federal." MARINONI, Luiz Guilherme. Precedentes Obrigatórios. São Paulo: RT, 2010. p. 459.

55 VIEIRA, Oscar Vilhena. Supremocracia. p. 445. 
De outro lado, cabe considerar que a Constituição Brasileira e a americana são bastante distintas, especialmente no que diz respeito à abrangência, como visto, e ao tempo de vigência de cada uma delas. Aliás, desde a porta do preâmbulo de cada uma das Constituições - a americana iniciando por "We the People" e a por "Nós, representantes do povo brasileiro", podem se arguir diferenças sintomáticas. ${ }^{56} \mathrm{Um}$ método interpretativo como o originalismo, em seu caráter subjetivo, pode soar ultrapassado nos Estados Unidos, mas é recente no Brasil. A história constitucional brasileira, nesse tema, faz com que nossa Constituição seja refratária, ao que deveria ser um de seus adjetivos elementares.

A Constituição não é só a norma fundamental, a Lei Maior de um país, que se coloca no vértice de todas as leis, mas também é desenhada para durar, pois molda "o caráter da sociedade e suas aspirações através da história [...]. É desenhada para guiar o comportamento humano por um longo período de tempo." ${ }^{57} \mathrm{O}$ lapso temporal é bastante relativo no caso nacional, uma vez que, calculado o tempo médio de duração de nossas Constituições, este é em torno de vinte e cinco anos.

A partir dessas breves colocações, deve-se proceder com cuidado ao se referir ao ativismo no Brasil. O termo não pode ser empregado para que seja abandonada a imparcialidade do Poder Judiciário, por considerá-la sinônima à neutralidade. $E$, inexistindo neutralidade, por se tratar de um "mito", não haveria imparcialidade. ${ }^{58} \mathrm{~A}$ conclusão é enganosa, e o desacerto está na premissa inicial, firmada na errônea assunção de, por conta do fato de o Poder Judiciário estar ligado ao "governo", e de ser inegável tratarem-se modernamente os tribunais de entes "políticos", não existe mais neutralidade. ${ }^{59}$

56 Em vez do povo, como no caso norte-americano, a Constituição brasileira foi elaborada pelos seus representantes. Não se trata de mera semântica ou fórmula vazia, pois o preâmbulo é uma espécie de "Constituição da Constituição", nas palavras de Peter Häberle, registrando também que funcionam como importantes "pontes no tempo, seja para evocar ou esconjurar o passado, a depender das circunstâncias históricas de cada processo constituinte; seja para falar ao presente, ocasionalmente orientando desejos; seja, enfim, para contemplar tanto o presente quanto o futuro e, com relação a este, ademais, para antecipar, quanto possível, o encontro de um povo com esse almejado porvir." Cf.: MENDES, Gilmar Ferreira, COELHO, Inocêncio Mártires, BRANCO, Paulo Gustavo Gonet. Curso de Direito Constitucional. 4 ed. São Paulo: Saraiva, 2009. p. 28-30. Registre-se, sob esse prisma, o preâmbulo da Constituição da República Portuguesa, verdadeiro testemunho histórico de que, a partir daquele momento, havia uma ruptura com o momento político anterior, efetuado pela Revolução de 25 de abril de 1974. CANOTILHO, J. J. Gomes; MOREIRA, Vital. Constituição da República Portuguesa anotada. São Paulo: RT, 2007. v. 1. p. 179.

57 BARAK, Aharon. Purposive Interpretation in Law. New Jersey: Princeton University Press, 2005. p. 370.

58 SOUZA, Artur César de. A parcialidade positiva do juiz. São Paulo: RT, 2008. p. 165.

59 SOUZA, Artur César de. A parcialidade positiva do juiz. p. 165. 
Quanto ao primeiro apontamento, trata-se de erro fundamental confundir Judiciário com Executivo pelo simples fato de serem ramos do Estado. O Executivo e o Legislativo são integrados por cargos submetidos a sufrágio e transitórios, enquanto que os do Judiciário são vitalícios ${ }^{60}$, entre outras garantias que asseguram sua independência. Ademais, é da natureza do Poder Judiciário que exerça poder político. ${ }^{61}$ De outra banda, há confusão entre o que se entende por imparcialidade e neutralidade do juiz. Como afirma Barbosa Moreira, imparcialidade é o que determina ao julgador que conduza o processo "sem inclinar a balança [...] para qualquer uma das partes, concedendo a uma delas, por exemplo, oportunidades mais amplas de expor e sustentar suas razões e de apresentar as provas de que disponha." ${ }^{162} \mathrm{~A}$ neutralidade, por outro lado, não é exigência de indiferença do magistrado. É natural, assevera o autor, que o juiz deseje a vitória e trabalhe em prol de quem está com a razão..$^{63}$ São conceitos inteiramente distintos e que não se encontram reciprocamente implicados. ${ }^{64}$ Esta breve referência já demonstra os riscos aos quais está submetido o 'maleável' conceito de ativismo judicial. O que pode ser considerado como ativismo, então, na perspectiva da doutrina brasileira?

Elival Ramos ${ }^{65}$ conceitua o ativismo judicial como "o desrespeito aos limites normativos substanciais da função jurisdicional", não caracterizado por toda e qualquer atividade que amplia o campo de incidência projetado por um enunciado normativo, em particular enunciados constitucionais. Verificase, segundo ele, pela ocorrência de excesso inaceitável, extrapolando o sentido

$\overline{60}$ Menciona-se a situação brasileira, a partir da dicção do art. 95 da CF. Outros ordenamentos, como o francês, asseguram, p. ex., aos membros do Conseil constitutionnel um mandato não renovável de nove anos, exigindose deles juramento específico e exercício imparcial do cargo. ZOLLER, Élisabeth. Droit Constitutionnel. $2^{\mathrm{a}}$ ed. Paris: PUF, 1998. p. 340.

61 GIULIANI, Alessandro; PICARDI, Nicola. La responsabilità del giudice. Ristampa aggiornata. Milano: Giuffrè, 1995. p. 225-226.

62 BARBOSA MOREIRA, José Carlos. Reflexões sobre a imparcialidade do juiz. Temas de direito processual: sétima série. São Paulo: Saraiva, 2001. p. 29.

63 BARBOSA MOREIRA, José Carlos. Reflexões sobre a imparcialidade do juiz. Temas de direito processual: sétima série. p. 30. O autor recorda a obra de Riedel, Das postulat der unparteilichkeit des richters, de 1980, na qual há crítica à indevida equiparação entre neutralidade e imparcialidade. Refere Barbosa Moreira sobre a obra alemã: "Esta última palavra [neutralidade], sustenta o autor, na medida em que sugere, para o juiz, uma abstenção de intervir ("Nicht-Intervention"), um distanciamento em relação ao litígio ("Vom-Konflikt-Fernbleiben"), expressa justamente o contrário do que afinal se espera dele."

64 Fica evidente estar repleta de ideologia perniciosa a "parcialidade positiva", pois seu objetivo é "romper com a totalidade do sistema vigente." SOUZA, Artur César de. A parcialidade positiva do juiz. São Paulo: RT, 2008. p. 170. Mais adiante, reforça a imperatividade de rompimento com a "racionalidade intrassistêmica" de "dogmática jurídica”. SOUZA, Artur César de. A parcialidade positiva do juiz. p. 277.

65 RAMOS, Elival da Silva. Ativismo Judicial: parâmetros dogmáticos. São Paulo: Saraiva, 2010,. p. 104 e ss. 
Novos Estudos Jurídicos

do dispositivo constitucional aplicado por interpretação descolada dos limites textuais. Com precisão, aponta que

[s]e, por meio de exercício ativista, se distorce, de algum modo, o sentido do dispositivo constitucional aplicado (por interpretação descolada dos limites textuais, por atribuição de efeitos com ele incompatíveis ou que devessem ser sopesados por outro poder etc.), está o órgão judiciário deformando a obra do próprio Poder Constituinte originário e perpetrando autêntica mutação inconstitucional, prática essa cuja gravidade fala por si só. Se o caso envolve o cerceamento da atividade de outro Poder, fundada na discricionariedade decorrente de norma constitucional de princípio ou veiculadora de conceito indeterminado de cunho valorativo, a par da interferência na função constituinte, haverá a interferência indevida na função correspondente à atividade cerceada (administrativa, legislativa, chefia de Estado etc.). É de se ressaltar, portanto, que o ativismo judicial em sede de controle de constitucionalidade pode agredir o direito vigente sob dois prismas diversos: pela deformação da normatividade constitucional e pela deformação, simultaneamente ou não, do direito infraconstitucional objeto de fiscalização, nessa última alternativa mediante, por exemplo, a indevida declaração de constitucionalidade ou de inconstitucionalidade de dispositivo legal ou de variante exegética a partir dele construída. ${ }^{66}$

A crítica demonstra a consternação causada por correntes perniciosas do ativismo, como a anteriormente referida, que sustenta a parcialidade positiva do juiz. De fato, a partir desse tipo de construto ativista, a Constituição (e, via de consequência, todo e qualquer cidadão) passa a correr sério risco de ver revogado ou completamente modificado seu catálogo aberto de direitos fundamentais, sem mencionar todos os demais direitos constitucionalmente assegurados. Sendo a Constituição mais do que um mero conjunto de normas, uma totalidade coesa de princípios e regras ${ }^{67}$, sua identidade reside neles, que não podem ser revisados, sob pena de instauração de uma nova ordem constitucional por meio de uma Corte Constitucional o que, além de ser uma aberrante afronta à separação dos poderes $^{68}$, é também uma violência, considerando que as Cortes Constitucionais não são constituintes, mas constituídas, e no exato pressuposto de guardar aquela que lhe constitui. Há de se reconhecer a existência de falhas no processo legislativo atual. Moroso, desinteressado e ineficaz, deve ser objeto de profunda reforma, desde a forma de escolha dos representantes até a possível modificação do

66 RAMOS, Elival da Silva. Ativismo Judicial. p. 106.

67 GUASTINI, Riccardo. Teoria e Ideologia da Interpretação Constitucional. p. 256.

68 ZOLLER, Élisabeth. Droit Constitutionnel. 2 ed. Paris: PUF, 1998, p. 309-314. 
processo em si. No entanto, uma resposta pragmática e imediata, como a que o Supremo Tribunal Federal vem entregando, não convive em sintonia com o preceito constitucional da separação de poderes (art. $2^{\circ}$ da CF/1988), pois a criação de leis não é a função própria do magistrado, que, em nosso caso, nunca é escolhido de forma democrática. ${ }^{69} \mathrm{Em}$ relação ao problema de se estabelecer quando a decisão é ativista, algumas notas de distinção entre os países também são necessárias.

Nos Estados Unidos encontram-se três diferentes standards de controle de constitucionalidade, "tendo como referência a distinta proteção que [...] a Constituição dispensa aos direitos fundamentais."70 No Brasil, Elival da Silva Ramos ${ }^{71}$ propõe também uma divisão diferenciada, em cinco níveis: (i) inexistência de controle (quando se trate de função de governo, pois não envolve a prática de atos concretos, e "mesmo o controle preventivo da constitucionalidade de atos do Poder Público jamais retroage a ponto de surpreender a planificação política da ação governamental"); (ii) controle mínimo (quando se trate de exercício jurisdicional pelo Poder Legislativo, como nos casos de crimes de responsabilidade do Presidente da República e de certas autoridades); (iii) controle médio fraco (atos interna corporis, atos de Chefia de Estado e controle de constitucionalidade fundado em princípios); (iv) controle médio forte (controle de constitucionalidade fundado em regras e de atos administrativos que haja discricionariedade); e, finalmente, (v) controle máximo (atos administrativos plenamente vinculados).

Essa escala progressiva, que aponta a diferente intensidade de atuação do Poder Judiciário, apresenta-se como uma das possíveis análises da mensuração da atividade dos juízes. Dependendo do tema analisado, verifica-se maior ou menor grau de liberdade de atuação do magistrado, com sensível alteração da intensidade de sua possível intervenção. Diante de situação de controle mínimo ou médio fraco, a atividade judicial é mais restrita, e qualquer tipo de excesso configurará ativismo judicial indevido e verdadeiramente violador da

69 Jeremy Waldron oferece dura crítica à Ronald Dworkin, argumentando que o judicial review é um procedimento não democrático e, portanto, sua instituição na Inglaterra, que era o objeto do debate, acarretaria, ao contrário do que entende Dworkin, uma perda para a democracia. Refere: "há sempre uma perda para a democracia quando uma visão sobre as condições da democracia é imposta por uma instituição não-democrática, mesmo quando a visão está correta e sua imposição melhora a democracia." Sua conclusão é de que a simples existência do judicial review não tornou os Estados Unidos um país mais justo, nem mais aberto ao debate. Cf. WALDRON, Jeremy. Law and Disagreement. Oxford: Oxford University Press. p. 302. No mesmo sentido: TUSHNET, Mark. Taking the Constitution away from the Courts. New Jersey: Princeton University Press, 1999. p. 154 e ss.

70 RAMOS, Elival da Silva. Ativismo Judicial. p. 112.

71 RAMOS, Elival da Silva. Ativismo Judicial. p. 113-123. 
separação dos poderes, pois demonstrada inserção ilegal do Poder Judiciário no âmbito de algum dos outros Poderes.

No entanto, há que se ressalvar que o ativismo judicial pode se verificar também nas relações estabelecidas exclusivamente entre particulares, e talvez a escala mencionada não consiga satisfatoriamente prevenir o fenômeno indesejado nessas situações. Em última ratio, o que se deseja evitar é não só a violação à separação de poderes, mas o exercício arbitrário do poder conferido aos juízes. Para tanto, será fundamental uma análise casuística, a fim de prevenir tal ocorrência. Mas esse posicionamento não parece ser o mais adequado à caracterização do ativismo. Ele não depende da intensidade da atuação do Poder Judiciário, mas sim da densidade normativa e da atuação do Legislativo. ${ }^{72} \mathrm{Ou}$ seja, se o Poder Legislativo cumpre, por exemplo, com sua função, como destinatário dos direitos fundamentais ${ }^{73}$, densificando-os, caberá ao Supremo Tribunal Federal o reconhecimento de eventual inconstitucionalidade, mas não de completa modificação do texto legal.

Tratando-se, por outro lado, de aplicação direta do texto constitucional, há de se reconhecer que a Constituição Federal possui diferentes densidades normativas. Nesses casos, a própria Carta estabelece, antes da atuação do Poder Judiciário, critérios que irão balizar uma maior ou menos intervenção. 0 rompimento dessas balizas é que caracteriza um indesejado ativismo judicial.

\subsection{DECISÕES PARADIGMÁTICAS}

Ainda que de maneira breve, faz-se necessária análise de quatro diferentes casos julgados pelo Supremo Tribunal Federal que demonstram a ocorrência de ativismo judicial. Os temas são os seguintes: a) execução provisória da pena; b) união homoafetiva; c) aborto de anencéfalo; e d) lei da ficha limpa.

No primeiro caso, o Supremo Tribunal Federal, em medida cautelar nas ADCs n. 43 e $44^{74}$, decidiu, por uma apertada maioria de 6 votos a 5, por conceder

72 Cf. ÁVILA, Humberto, em aula ministrada no Programa de Pós-Graduação em Direito da Faculdade de Direito da UFRGS em 12.12.2012, na Disciplina Interpretação e Argumentação (DIRP 180).

73 SARLET, Ingo Wolfgang, MARINONI, Luiz Guilherme, MITIDIERO, Daniel. Curso de Direito Constitucional. São Paulo: RT, 2012. p. 615-616.

74 BRASIL. Supremo Tribunal Federal. Ação Declaratória de Constitucionalidade n. 43 e 44 . Relator para acórdão Min. Edson Fachin, 2016. 
interpretação conforme ao art. 283 do Código Penal ${ }^{75}$, entendendo que a execução provisória da sentença criminal, quando assentada em condenação pelo segundo grau de jurisdição, não violaria a Constituição Federal. O julgamento é entendido de caráter ativista, considerando que o dispositivo constitucional de referência (art. 5, LVII, da $\mathrm{CF}^{76}$ ) alude à consideração de culpa apenas após o trânsito em julgado, enquanto o citado dispositivo legal não parece mais do que a especificação da regra constitucional. Desse modo, a Corte entendeu inconstitucional uma leitura da lei que, em síntese, parecia repetir o texto da Constituição. Nos votos condutores, preferiam-se, por vezes, fundamentos de ordem "pragmática" e "empírica" (os altos índices de corrupção no país e a necessidade de uma resposta a essas condutas) à análise desses textos e seu significado, como ficou claro em recente julgado da corte que, com base naquele entendimento, houve por negar habeas corpus $^{77}$ a Luís Inácio Lula da Silva, que se tornou assim o primeiro expresidente da República a ser preso por condenação de crime comum.

No segundo caso, ao julgar a ADIN n. 4277 e a ADPF n. 132, os Ministros do Supremo Tribunal Federal afirmaram ter realizado interpretação conforme a Constituição do art. 1723 do Código Civil para que, a partir da vedação de discriminação prevista no art. $3^{\circ}$, IV da Constituição Federal, fosse permitida a união de pessoas do mesmo sexo. E, para o entendimento de alguns juristas, dada a dicção do art. 1726 do Código Civil78, o Supremo teria legalizado o "casamento gay". Uma questão relevante é a de que, a partir da leitura do art. 226, parágrafo $3^{\circ}$, da Constituição, verifica-se que seria necessário também um enfrentamento desse texto normativo, e não somente do Código Civil, para que se pudesse falar a respeito da união homoafetiva. O que se verificou foi que o Supremo procedeu à inovação legislativa de ordem muito significativa, mudança esta que, em outros países, foi realizada pelo próprio Poder Legislativo, caso da Argentina (2010, primeiro da América Latina a aprová-la nacionalmente), Espanha (2005), Canadá (2005) e Bélgica (2003). Em qualquer desses países, a aprovação da Lei gerou controvérsia e muito debate entre os setores conservador e liberal da sociedade.

75 Art. 283. Ninguém poderá ser preso senão em flagrante delito ou por ordem escrita e fundamentada da autoridade judiciária competente, em decorrência de sentença condenatória transitada em julgado ou, no curso da investigação ou do processo, em virtude de prisão temporária ou prisão preventiva.

76 Art. $5^{\circ}$, LVII: ninguém será considerado culpado até o trânsito em julgado de sentença penal condenatória.

77 BRASIL. Supremo Tribunal Federal. Habeas Corpus n. 152.752. Relator Min. Edson Fachin, 2018.

78 Art. 1.726. A união estável poderá converter-se em casamento, mediante pedido dos companheiros ao juiz e assento no Registro Civil. 
No terceiro caso, no julgamento da ADPF n. 54, permitiu-se a possibilidade de interrupção da gravidez quando constatada a anencefalia fetal, o que tornaria o nascituro inviável, vindo a morrer poucos momentos depois do parto. $O$ argumento utilizado pelo relator, Min. Marco Aurélio ${ }^{79}$, foi o de que o feto, nessas condições, embora biologicamente vivo, era juridicamente morto, pois não gozava de proteção estatal. Outro argumento amplamente utilizado, tanto pelo relator como por outros Ministros, foi o de que a gestação de feto anencéfalo poderia vir a acarretar risco de vida para a mãe, o que já era permitido pelo art. 128, I, do Código Penal. No entanto, a decisão foi mais além: admitiu-se a prática do aborto para prevenir a mãe das consequências psicológicas deletérias de parir um natimorto. O Supremo Tribunal Federal acabou, na realidade, incluindo no Código Penal mais uma possibilidade de aborto legal, abrindo margem à discussão de o que possa vir a significar "risco de vida" para a mãe. Mais recentemente, a Primeira Turma do Tribunal, como referido anteriormente, ampliou o entendimento e, em decisão seguramente ativista, porque desencontrada com o texto do Código Penal e com sua interpretação histórica, houve por descriminalizar o aborto ocorrido nos três primeiros meses de gestação. ${ }^{80}$

Quanto ao último caso, a respeito do julgamento da Lei da Ficha Limpa (Lei Complementar 135/10), nas Ações Declaratórias de Constitucionalidade n. 29 e 30 e na Ação Direta de Inconstitucionalidade n. 4578, discutia-se sua aplicabilidade ao pleito eleitoral de 2012. Destacou-se o voto do Ministro Luiz Fux ${ }^{81}$, de evidente nota ativista, que se valeu da utilização do princípio da segurança jurídica em detrimento do texto constitucional expresso, que assegura o direito adquirido e, mais claramente, a noção de irretroatividade da lei, optando pela aplicação da tese da retrospectividade (ou retroatividade inautêntica), não vedada pela Constituição. O ativismo transparece, por outro lado, na medida em que o Min. Luiz Fux refere a necessidade de overruling dos precedentes relativos à matéria da presunção

79 BRASIL. Supremo Tribunal Federal. Arguição de Descumprimento de Preceito Fundamental n. 54. Relator Min. Marco Aurélio, 2012.

80 BRASIL. Supremo Tribunal Federal. Habeas Corpus n. 124.306. Relator para acórdão Min. Roberto Barroso, 2016.

81 BRASIL. Supremo Tribunal Federal. Ação Direta de Inconstitucionalidade no 4.578/DF. Relator Min. Luiz Fux, 2014. 


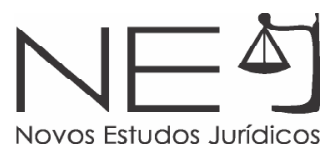

de inocência vis-à-vis inelegibilidades. Não se trata de mudança de perspectiva, trata-se de mudança no texto da própria lei, que autorizava sua aplicação. Assim, não há alteração de precedente, mas tão somente aplicação da nova lei.

\section{CONSIDERAÇÕES FINAIS}

O "papel iluminista" das Cortes Constitucionais, viu-se, resgata o debate, tão conhecido como relevante, do ativismo versus autocontenção. E esse, por seu turno, perpassa temas fundamentais, como a separação dos poderes e também a própria noção de democracia. Conquanto a democracia tenha, em seu núcleo, a exigência de tolerância - notadamente com os entendimentos contrários -, há, nesse seu mesmo núcleo, balizas procedimentais que exigem certa intolerância, sob pena de a abandonar. E uma dessas balizas está na não usurpação dos papéis concedidos a cada um dos poderes desde a formação dos Estados Democráticos de Direito.

Diante da dação de protagonismo ao Poder Judiciário, a ideia de um "papel iluminista" do Supremo Tribunal Federal, descortinada por Luís Roberto Barroso, é de fundamental importância para lançar um debate profundo que se deve fazer sobre a missão da mais alta Corte Constitucional, notadamente para definir o que realmente significa, nos termos do art. 102 da Constituição Federal, a competência desse Tribunal de "guardar a Constituição".

Conhecida a origem do ativismo judicial no direito da common law, e da necessidade de sua distinção com aquele que se pratica no Brasil, aquilo que se poderia chamar de um ativismo à brasileira, nesse contexto, parece, com feito, ofender a segurança jurídica ${ }^{82}$, em seus caracteres de cognoscibilidade (na medida em que as decisões de cunho ativista impedem a plena capacidade de "compreensão das alternativas interpretativas e dos critérios indispensáveis à sua determinação"83), da confiabilidade (a mudança social que se espera do Poder Judiciário não pode advir de ataques à competência do Legislativo e, portanto, em violação da separação dos poderes) e da calculabilidade (a capacidade de antecipação do conteúdo das decisões torna-se praticamente impossível, se os

82 A respeito dos caracteres formadores da segurança jurídica, vide ÁVILA, Humberto. Segurança Jurídica. 2 ed. São Paulo: Malheiros, 2012. p. 256-258. Justamente pelo ativismo ofender a segurança jurídica, como colocado, é que surpreende o fato de o Min. Luiz Fux, nas ADCs 29 e 39 e ADI 4578, valer-se da própria segurança ao deixar de aplicar a disposição constitucional que trata da irretroatividade da lei.

ÁVILA, Humberto. Segurança Jurídica. p. 257. 
juízes não estão vinculados à lei ou à Constituição, permitindo-se uma leitura livre, aberta e irresponsável do texto constitucional). Se, por outro lado, o principal fundamento que transparece como autorizador desse empoderamento do Poder Judiciário é que o Executivo e o Legislativo desejam se afastar do debate de temas difíceis, a fim de que a "pressão popular" não seja levada em conta, há nele um efeito deletério. Isso porque a excessiva judicialização de temas políticos por natureza acaba por oferecer um refúgio à classe política (Legislativo e Executivo), que se escuda no Judiciário, evitando a tomada de decisões difíceis com relação a esses temas na sua arena natural: o Parlamento, que é o lugar do povo. ${ }^{84}$

Nessa linha, a decorrência natural é a manutenção do status quo político e a estabilidade no Legislativo e no Executivo, ao menos por não se envolverem diretamente em tais questões. A ADPF n. 54 serve como exemplo. Distribuída em junho de 2004, transcorreram-se oito anos entre a distribuição e o julgamento, sem que o Legislativo desse espaço ao debate do tema, razão de a Ministra Ellen Gracie assim se manifestar na Questão de Ordem:

Parece-me profundamente antidemocrático pretender obter, por essa via tão tortuosa da ADPF, manifestação a respeito de um tema que, por ser controverso na sociedade brasileira, ainda não logrou apreciação conclusiva do Congresso Nacional, ainda que registradas tantas iniciativas legislativas em ambas as Casas. Não há o Supremo Tribunal Federal de servir como "atalho fácil" para a obtenção de resultado - a legalização da prática do abortamento - que os representantes eleitos do povo brasileiro ainda não se dispuseram a enfrentar.

A defesa de um "iluminismo constitucional" - como um subterfúgio à alternativa ativista -, por esses motivos, mostra-se perigosa. Especialmente quando se percebem, em sua justificativa, exemplos com características distintas apresentadas como o mesmo fenômeno. Parece evidente que a conclusão de Brown v. Board of Education, por exemplo, é ativista no sentido original do termo. Mas é necessário concluir que a decisão é extraível, dentro da referida "zona de razoabilidade judicial", uma vez que se tratava de uma interpretação possível (e, seguramente, a melhor) considerando a textura aberta da "equal protection clause". O mesmo não se pode dizer, contudo, na leitura de disposição com textura fechada, como a regra que não permite consideração de culpa antes do trânsito em julgado da sentença penal condenatória

84 HIRSCHL, Ran. Towards Juristocracy. Massachusetts: Harvard University Press, 2004. p. 213. 


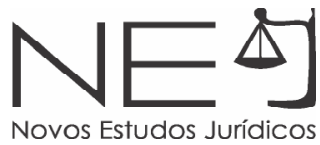

Não se pode, pois, confundir decisões de vanguarda ( $e$, nesse sentido, ativistas) de Tribunais Constitucionais estabelecidas dentro da multiplicidade de significados extraíveis naturalmente dos textos, com decisões cuja vanguarda advém de verdadeira ginástica hermenêutica desses textos, para deles fazer extrair aquilo que, ainda que politicamente desejável, é juridicamente inaceitável, a considerar a autolimitação. Há, assim, uma ética inerente à autolimitação judicial, pois parte ela de uma declaração de humildade do juiz: aquela de dizer que o texto, que constitui sua jurisdição, há de ser maior que ele em sua jurisdição.

Iluminar o texto, seguramente, é papel dos juristas ao menos desde que o direito passou a ser estudado nas universidades, valendo lembrar que a Irnerius, o mais notável jurista da Escola dos Glosadores, foi dada a alcunha de "lucerna iuris", isso é, de "a lanterna do direito". Tal iluminismo passa, como ensinou Kant, pelo uso público da razão, o que se identifica, em direito, com o dever de fundamentação adequada.

Mas, ao iluminar os textos, fundamentando-os, devem os juristas, notadamente aqueles que exercem a função de guarda da Constituição, ter no seu texto o limite de sua liberdade. Não podem acreditar, nem por um momento, que são mais iluminados que os constituintes, porque isso equivaleria a dizer que se arvoram no papel de iluminar o próprio povo, na escuridão da qual ele mesmo seria culpado, quiçá por não pensar como o juiz iluminista. Um déspota esclarecido, afinal, não deixa de ser um déspota.

\section{REFERÊNCIAS DAS FONTES CITADAS}

ÁVILA, Humberto. Segurança Jurídica. 2 ed. São Paulo: Malheiros, 2012.

BARAK, Aharon. Purpsosive Interpretation in Law. Tradução (do hebraico) de Sari Bashi. New Jersey: Princeton University Press, 2005.

BARAK, Aharon. The Judge in a Democracy. New Jersey: Princeton University Press, 2006. BARAK, Aharon. The Role of a Supreme Court in a Democracy. Hastings Law Journal, v. 53, 2001-2002.

BARBOSA MOREIRA, José Carlos. Reflexões sobre a imparcialidade do juiz. Temas de direito processual: sétima série. São Paulo: Saraiva, 2001. 
BARROSO, Luís Roberto. Posfácio. Contramajoritário, representativo e iluminista: o Supremo, seus papéis e seus críticos. In: VIEIRA, Oscar Vilhena; GLEZER, Rubens. A razão e o Voto: diálogos constitucionais com Luís Roberto Barroso. Rio de Janeiro: FGV Editora, 2017.

BEDAQUE, José Roberto dos Santos. Poderes Instrutórios do Juiz. 4 ed. São Paulo: RT, 2009. BICKEL, Alexander M. The Least Dangerous Branch. 2 ed. New Haven: Yale University Press, 1986.

BRASIL. Supremo Tribunal Federal. Ação Declaratória de Constitucionalidade n. 43 e 44. Relator para acórdão Min. Edson Fachin, 2016.

BRASIL. Supremo Tribunal Federal. Ação Direta de Inconstitucionalidade no 4.578/DF. Relator Min. Luiz Fux, 2014.

BRASIL. Supremo Tribunal Federal. Ação Direta de Inconstitucionalidade n. 4277. Relator Min. Ayres Britto, 2011.

BRASIL. Supremo Tribunal Federal. Arguição de Descumprimento de Preceito Fundamental no 54. Relator Min. Marco Aurélio, 2012.

BRASIL. Supremo Tribunal Federal. Arguição de Descumprimento de Preceito Fundamental $\mathrm{n}$. 132. Relator Min. Ayres Britto, 2011.

BRASIL. Supremo Tribunal Federal. Habeas Corpus n. 124.306. Relator para acórdão Min. Roberto Barroso, 2016.

BRASIL. Supremo Tribunal Federal. Habeas Corpus n. 152.752. Relator Min. Edson Fachin, 2018.

BRASIL. Supremo Tribunal Federal. Recurso Extraordinário n. 330.817. Relator Min. Dias Toffoli, 2017.

CANIVET, Guy. Activisme judiciaire et prudence interpretative. La Création du droit par le juge, Archives de philosophie du droit. T. 50. Paris: Dalloz, 2007.

CANOTILHO, J. J. Gomes; MOREIRA, Vital. Constituição da República Portuguesa anotada. v. 1. São Paulo: RT, 2007.

CARDOZO, Benjamin. The nature of the judicial process. New York: Dover Publications, 2005. CARTER, John Denton. The Warren Court and the Constitution. Lousiana: Pelican Publishing Company, 1973.

CHEMERINSKY, Erwin. Conservative Judicial Activism. Loyola of Los Angeles Law Review, v. 44, 2010-2011. 


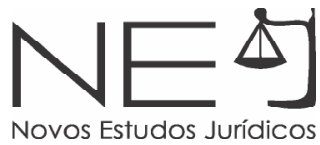

CORDER, Hugo. Judicial Activism of a Special Type: South Africa's Top Courts since 1994. In: DICKSON, Brice (org.). Judicial Activism in Common Law Supreme Courts. Oxford: Oxford University Press, 2007.

CROSS, Rupert, HARRIS, J. W. Precedent in English Law. Oxford: Clarendon Press, 2004.

DICEY, A. V. The Law of the Constitution. Indianapolis: Liberty Fund, 1982.

DIMOULIS, Dimitri, LUNARDI, Soraya Gasparetto. Ativismo e Autocontenção judicial no controle de constitucionalidade. In: As novas faces do ativismo judicial. Salvador: Juspodivm, 2011.

GIULIANI, Alessandro; PICARDI, Nicola. La responsabilità del giudice. Ristampa aggiornata. Milano: Giuffrè, 1995.

GUASTINI, Riccardo. Interpretare e Argomentare. Milano: Giuffrè, 2011.

GUASTINI, Riccardo. Teoria e Ideologia da Interpretação Constitucional. Interesse Público, Sapucaia do Sul , v. 8, n. 40, p. 217-256, nov. 2006.

HAMILTON, Alexander; JAY, John; MADISON, James. O federalista. Rio de Janeiro: Editora Nacional de Direito, 1959.

HIRSCHL, Ran. Towards Juristocracy. Massachusetts: Harvard University Press, 2004.

KANT, Immanuel. Beantwortung der Frage: Was ist Aufklärung? Berlinische Monatsschrift. Dezember-Heft, 1784, p.481-494. Disponível em: <http://www.uni-potsdam.de/u/philosophie/ texte/kant/aufklaer. htm>. Acesso em: 10 abr. 2018.

LEVY, Leonard W. Original Intent and the Framer's Constitution. New York: Macmillan Publishing Co., 1988.

MARINONI, Luiz Guilherme. Precedentes Obrigatórios. São Paulo: RT, 2010.

MENDES, Gilmar Ferreira, COELHO, Inocêncio Mártires, BRANCO, Paulo Gustavo Gonet. Curso de Direito Constitucional. 4 ed. São Paulo: Saraiva, 2009.

MENEZ, Joseph F.; VILE, John R. Summaries of leading cases on the constitution: 50th anniversary edition. Lanham: Rowman \& Littlefield Publishers, 2004, Disponivel em: <http:// caselaw.lp.findlaw.com/scripts/getcase.pl?court=us\&vol=5\&invol=137>. Acesso em: 18 abr. 2018.

ORIGGI, Gloria. Qu'est-ce que la confiance? Paris: Librairie Philosophique J. Vrin, 2008. POPOVIC, Dragoljub. Prevailing of judicial activism over self-restraint in the jurisprudence of the european court of human rights. Creighton Law Review, vol. 42, p. 361-396, 2008-2009.

POSNER, Richard. How Judges Think. Cambridge: Harvard University Press, 2008.

RAMOS, Elival da Silva. Ativismo Judicial: parâmetros dogmáticos. São Paulo: Saraiva, 2010. 
SARLET, Ingo Wolfgang, MARINONI, Luiz Guilherme, MITIDIERO, Daniel. Curso de Direito Constitucional. São Paulo: RT, 2012.

SOUZA, Artur César de. A parcialidade positiva do juiz. São Paulo: RT, 2008.

TARUFFO, Michele. La motivazione della sentenza civile. Padova: CEDAM, 1975.

TERRÉ, François. Um juge créateur de droit? Non merci! La Création du droit par le juge, Archives de philosophie du droit. T. 50. Paris: Dalloz, 2007.

TUSHNET, Mark. Taking the constitution away from the courts. New Jersey: Princeton University Press, 1999.

VIEIRA, Oscar Vilhena. Supremocracia. Revista Direito GV, São Paulo: RT, v. 8, p. 441-464, jul./ dez.2008.

WAELE, Henri de, VLEUTEN, Ana van der. Judicial activism in the european court of justice the case of LGBT rights. Michigan State University Journal of International Law, vol. 19, p. 639-666, 2010-2011.

WALDRON, Jeremy. Law and Disagreement. Oxford: Oxford University Press, 1999.

WHEELER, Fiona, WILLIAMS, John. 'Restrained Activism' in the High Court of Australia. In: DICKSON, Brice (org.). Judicial Activism in Common Law Supreme Courts. Oxford: Oxford University Press, 2007.

ZAFFARONI, Eugenio Raúl. Poder judiciário: crise, acertos e desacertos. Tradução de Juarez Tavares. São Paulo: RT, 1995.

ZOLLER, Élisabeth. Droit Constitutionnel. 2 ed. Paris: PUF, 1998.

ZOLLER, Élisabeth. La Cour suprême des États-Units entre création et destruction du droit. La Création du droit par le juge, Archives de philosophie du droit, T. 50. Paris: Dalloz, 2007.

Recebido em: 26/06/2018

Aprovado em: 22/04/2019 